\title{
PERAN BANK INDONESIA DALAM MENANGGULANGI TINDAK PIDANA MONEY LAUNDERING
}

\author{
Budi Setiyanto
}

\begin{abstract}
The aim of the study is to understand the role and constraints of Bank Indonesia in eradicating the crime of money laundering. This research included in empirical legal research is a descriptive qualitative. Location of research at Bank Indonesia Solo. The data used are primary and secondary data, data collections by interview and literature study, analysis of data using qualitative analysis. Based on the results of this research is that Bank Indonesia in order to participate as well as eradicating crime of money laundering and has issued a Circular Letter of Bank Indonesia. In the implementation of supervision and oversight of the implementation of Programme Implementation of Anti-Money Laundering (Money Laundering), Bank Indonesi requires each commercial bank to report the results of the Application of Anti-Money Laundering Program Compliance to the Chair through the Director of Public Bank. Head of Commercial Bank submitted the report to the Head Office of Bank Supervision of Bank Indonesia Solo through the Young Senior, having studied and revised and then submitted to the Head of Bank Indonesia Central Jakarta. In the implementation of the Application of Anti-Money Laundering Program, Office of Bank Indonesia Solo, many having some problems so it can not work optimally.
\end{abstract}

Keywords: Money Laundering crime, Bank Indonesia.

\section{A. Pendahuluan}

Indonesia saat ini sedang mengalami proses globalisasi sehingga akan berpengaruh juga terhadap kemajuan hubungan dalam bidang ekonomi dan teknologi, dan hal tersebut akan berakibat adanya kecenderungan meningkatnya tindak pidana ekonomi di bidang perbankan. Salah satu kejahatan ekonomi di bidang perbankan yang relatif baru dan mulai berkembang dengan pesatnya adalah kegiatan atau praktek pencucian uang (money laundering) yang juga dapat bersifat lintas batas teritorial. Kejahatan money laundering tersebut telah diatur dalam Undang-Undang Nomor 15 tahun 2002 tentang Tindak Pidana Pencucian Uang (Lembaran Negara Tahun 2002 Nomor 30) sebagaimana telah dirubah dengan Undang-Undang Nomor 25 Tahun 2003).

Di dalam Pasal 1 ayat (1) disebutkan bahwa yang dimaksud dengan Pencucian Uang adalah perbuatan menempatkan, menstransfer, membayarkan, membelanjakan, menghibahkan, menyumbangkan, menitipkan, membawa ke luar negeri, menukarkan, atau perbuatan lainya atas harta kekayaan yang diketahui atau patut diduga merupakan hasil tindak pidana dengan maksud untuk menyembunyikan, atau menyamarkan asal usul harta kekayaan sehingga seolah-olah menjadi harta kekayaan yang sah.

Berkaitan tindak pidana money laundering, penting sekali peranan dunia perbankan dalam melancarkan kegiatan praktek pemutihan uang tersebut. Para pelaku money laundering mempergunakan bank sebagai alat untuk mencuci uang hasil kejahatan mereka melalui bergai instrument, hal ini sehubungan dengan adanya ketentuan di bidang perbankan dimana sangat menguntungkan para pelaku money laundering. Ada ketentuan yang sebenarnya sangat menguntungkan para pelaku money laundering tersebut dibidang perbankan, yaitu tentang ketentuan kerahasiaan bank (diatur dalam Pasal 40 W No. 10 Tahun 1998 tentang Perubahan Atas Undang-Undang No. 7 Tahun 1992 tentang Perbankan) Mengenai rahasia bank ini, sebenarnya tidak seketat yang dibayangkan karena Undang-Undang No. 10 Tahun 1998 juga telah memberikan pengecualian seperti 
yang diatur dalam Pasal 41, 41A, 42, 44 dan pasla 144A.

Dalam kejahatan money laundering, bank digunakan sebagai sarana untuk melakukan kejahatan. Selain itu bank dapat juga sebagai pelaku korporasi untuk melakukan tindakan pidana perbankan (diatur dalam Pasal 49 UU No. 10 Tahun 1998) dengan tujuan untuk mempermudah dilakukannya tindak pidana money laundering. Untuk mengantisipasi hal tersebut maka perlu adanya pengwasan terhadap kegiatan operasional bank sesuai dengan ketentuan Pasal 29 ayat (1) Undang-Undang Nomor 10 Tahun 1998 Tentang Perubahan Atas Undang-Undang No. 7 Tahun 1992 tentang Perbankan yang menyatakan bahwa; Pembinaan dan Pengawasan Bank dilakukan oleh Bank Indonesia, selanjutnya Pasal 34 Undang-Undang No. 31999 tentang Bank Indonesia menyatakan bahwa, "Tugas mengawasi Bank akan dilakukan oleh lembaga pengawas sektor jasa keuangan yang independent, dan dibentuk dengan undang-undang”. Pembentukan lembaga pengawasan akan dilaksanakan selambatlambatnya 31 Desember 2010. berdasarkan ketentuan tersebut, maka sebelum dibentuk lembaga pengawas, Bank Indonesia masih berwenang untuk melakukan tugas pembinaan dan pengawasan terhadap kegiatan operasional bank.

Dalam rangka pelaksanaaan tugas pembinaan dan pengawasan terhadap kegiatan operasional bank, maka Bank Indonesia telah mengeluarkan beberapa Peraturan Bank Indonesia (PBI) dan Surat Edaran Bank Indonesia (SEBI) maupun Surat Keputusan Direksi yang dengan produk ketentuan yang telah dikeluarkannya dapat sebagai alat yang berhubungan dengan anti pencucian uang (money laundering). Meskipun ketentuanketentuan tersebut tidak bersifat langsung, akan tetapi dapat dijadikan sebagai dasar hukum untuk mencegah dan mengurangi atau merupakan penanggulangan suatu gejala ("kurieren am sympton") atau dengan kata lain penanggulangan secara preventif terhadap kegiatan money laundering.

B. Tinjauan Pustaka

1. Tinjauan Tentang Bank
Menurut Abdurrachman, secara terminologi, istilah "bank" berasal dari bahasa Italia "banca" yang berarti "bence" yaitu suatu bangku atau tempat duduk. Sebab pada zaman pertengahanh, pihak bankir Italia yang memberikan pinjaman-pinjaman melakukan usahanya tersebut dengan duduk di bangku-bangku halaman pasar (Munir Fuady, 2001: 13). Pengertian bank dalam kamus perbankan diartikan sebagai badan usaha di bidang keuangan, yang menarik uang dari dan menyalurkannya kedalam masyarakat, terutama dengan memberikan kredit dan jasa dalam lalu lintas pembayaran dan peredaran uang.

adalah $\begin{array}{r}\text { Menurut } \\ \text { badan }\end{array}$ usahanans bank melaksanakan kegiatan menghimpun dana dari masyarakat dan menyalurkannya kembali kepada pihak-pihak yang membutuhkan dalam bentuk kredit dan memberikan jasa dalam lalu lintas pembayaran (Hermansyah, 2005: 8).

Di Indonesia pengertian bank diatur dalam Undang-Undang No. 10 Tahun 1998 tentang Perubahan Undang-Undang No. 7 Tahun 1992 tentang Perbankan Pasal 1 angka 2 yang menyebutkan,

"Bank adalah badan usaha yang menghimpun dana dari masyarakat dalam bentuk simpanan dan menyalurkannya kepada masyarakat dalam bentuk kredit dan atau bentuk-bentuk lainnya dalam rangka meningkatkan taraf hidup rakyat banyak".

Pada hakekatnya, pengertian bank dari berbagai pendapat para ahli hampir sama, bahwa bank merupakan tempat penitipan atau penyimpanan uang, pemberi atau penyalur kredit dan juga perantara di dalam lalu lintas pembayaran. Ada beberapa macam bank-bank antara lain ialah:

Macam-macam Bank

1). Dilihat dari segi fungsinya

a). Bank Sentral (Central Bank)

b). Bank Umum ( Commercial Bank ) 
c) Bank Tabungan ( Saving Bank )

d). Bank Pembangunan (Development Bank)

e). Bank Desa (Rural Bank)

2). Dilihat dari segi kepemilikannya, bank terbagi dalam:

a). Bank Milik Pemerintah

b). Bank Milik Swasta Nasional

c). Bank Milik Koperasi

d). Bank Milik Asing

e). Bank Milik Campuran

3). Dilihat dari segi atau cara menentukan harga baik harga jual maupun

harga beli:

a). Bank berdasarkan prinsip konvensional, yaitu bank yang dalam

mencari keuntungan dan menentukan harga kepada nasabahnya, bank yang berdasarkan prinsip konvensional menggunakan metode yaitu menetapkan bunga sebagai harga, baik untuk produk pinjaman (kredit) juga ditentukan berdasarkan tingkat suku bunga tertentu.

b). Bank berdasarkan prinsip syariah, yaitu bank yang menerapkan aturan

syariah atau perjanjian berdasarkan hukum Islam antara bank dengan pihak lain untuk menyimpan dana atau pembiayaan usaha atau kegiatan perbankan lainnya. Bank berdasarkan prinsip bagi hasil, prinsip penyertaan modal, jual beli barang dengan memperoleh keuntungan dan lain sebagainya (Johanes Ibrahim: 41-42)

4). Dilihat dari kedudukan atau status
a). Bank Devisa
b). Bank Non Devisa

5). Bank menurut Undang-Undang Nomor 10 Tahun 1998 Tentang

Perubahan Atas Undang-Undnag Nomor 7 Tahun 1992 Tentang Perbankan tercantum didalam Pasal:

a). Bank Umum, yaitu bank yang melaksanakan kegiatan usaha secara konvensional dan atau berdasrkan prinsip syariah, yang dalam kegiatannya memberikan jasa dalam lalu lintas pembayaran.

b). Bank Perkreditan Rakyat, yaitu bank yang melaksanakan kegiatan

usaha secara konvensional atau berdasarkan prinsip syariah yang dalam tidak memberikan jasa dalam lalu lintas pembayaran.

Mengenai fungsi perbankan Indonesia secara umum diatur dalam Pasal 3 Undang-Undang Nomor 7 Tahun 1992 yaitu: sebagai penghimpun dan penyalur dana masyarakat, sedangkan didalam Pasal 4 Undang-Undang Nomor 7 Tahun 1992 disebutkan tentang tujuan perbankan nasional dalam ranka meningkatkan pemerataan pertumbuhan ekonomi, dan stabilitas nasional ke arah peningkatan kesejahteraan rakyat banyak.

2.Status, Kedudukan dan Tugas Bank Indonesia

Salah satu butir kesepakatan yang ditandatangani oleh pemerintah Indoensia dengan International Monetery Foundation (IMF) pada tanggal 15 Januari 1998 adalah keharusan mengubah status dan fungsi Bank Indonesia menjadi Bank Sentral yang independen. Babak baru dalam sejarah Bank Indonesia sebagai bank sentral yang independen dimulai ketika sebuah undangundang baru, yaitu Undang-Undang Nomor 23 tahun 1999 Tentang Bank Indonesia dinyatakan berlaku sejak tanggal 17 Mei 1999. Kemudian Undang-Undang Nomor 23 Tahun 1999 diubah oleh Undang-Undang Nomor 3 Tahun 2004 Tentang Perubahan Atas Undang-Undang Republik Indonesia Nomor 23 Tahun 1999 Tentang Bank Indonesia, tidak semua pasal diubah hanya pasal-pasal tertentu saja. Status dan kedudukan Bank Indonesia ditentukan didalam pasal 4 ayat $(1,2$, dan 3) UndangUndang Nomor 3 Tahun 2004. 
$\begin{array}{llr} & \text { Bank Indonesia sebagai } \\ \text { suatu lembaga negara yang }\end{array}$ independen, mempunyai otonom penuh dalam merumuskan dan melaksnakan setiap tugas dan wewenanganya sebagaimana ditentukan dalam undangundang.pihak luar tidak dibenarkan mencampuri pelaksanaan tugas Bank Indonesia, dan Bank Indonesia juga berkewajiban untuk menolak atau mengabaikan interval dalam bentuk apapun dari pihak manapun juga. Pelanggaran terhadap larangan melakukan campur tangan terhadap tugas Bank Indonesia, maupun Dewan Gubernur, dan Pejabat Bank Indonesia yang tidak menolak campur tangan pihak lain dikenai ancaman pidana dan denda yang besar.

Status Bank Indonesia sebagai badan hukum baik sebagai badan publik maupun badan hukum perdata ditetapkan dengan UndangUndang. Sebagai badan hukum publik Bank Indonesia berwenang menetapkan peraturan-peraturan hukum yang merupakan pelaksanaan dari Undang-Undang yang mengikat seluruh masyarakat luas sesuai tugas dan wewenangnya. Dalam melaksanakan tugasnya, Bank Indonesia mempunyai hubungan kerja dengan DPR, BPK, dan pemerintah. Bank Indonesia juga dapat melakukan kerjasama dengan bank sentral lainnya. Organisasi internasional, dan lembaga internasional serta dapat menjadi anggota pada lembaga multilateral baik atas nama Bank Indonesia maupun mewakili pemerintah. Tugas dan wewenang Bank Indonesia antara lain:

Menetapkan dan melaksanakan kebijakan moneter

b. Mengatur dan menjaga kelancaran sistem pembayaran

c. Mengatur dan mengawasi Bank

Pengawasan bank oleh Bank Indonesia dapat dilakukan baik langsung maupun tidak langsung. Dalam hal keadaan suatu bank menurut penilaian Bank Indonesia membahayakan kelangsungan usaha bank yang bersangkutan dan /atau membahayakan sistem perbankan atau terjadi kesulitan perbankan yang membahayakan perekonomian nasional, Bank Indonesia dapat melakukan tindakan sebagaimana diatur dalam undang-undang perbankan yang berlaku (Sentosa Sembiring, 2000: 79).

Tugas dan wewenang Bank Indonesia diatur di dalam Pasal 29, 31, 37, 37 A Undang-Undang Nomor 10 Tahun 1998 Tentang Perubahan Atas Undang-Undang Nomor 10 Tahun 1998 Tentang Perubahan Atas Undang-Undang Nomor 7 Tahun 1992 Tentang Perbankan dan didalam Pasal 10, 11, 34, 38 Undang-Undang Nomor 3 Tahun 2004 Tentang Perubahan Atas Undang-Undang Nomor 1999 Tentang Bank Indonesia.

3. Tinjauan Tentang Money Laundering a. Pengertian Money Laundering

Terdapat bermacammacam pengertian tentang money laundering, namun semua tetap dalam satu tujuan untuk menyatakan bahwa money laundering ialah satu kejahatan yang potensial dalam mengancam berbagai kepentingan baik dalam skala nasional maupun internasional. Money laundering merupakan sebuah istilah yang pertama kali digunakan di Amerika Serikat. Istilah tersebut menunjukkan kepada pencucian hak milik mafia yaitu hasil usaha yang diperoleh secara gelap yang dicampurkan dengan maksud menjadikan seluruh hasil tersebut seolah-olah diperoleh dari sumber yang sah. Dalam

perkembangannya, proses yang dilakukan lebih komplek lagi dan dengan menggunakan cara mutakhir sedemikian rupa sehingga seolah-olah uang yang diperoleh benar-benar alami. Karena itu wajar jika dalam The National Money Laudering Strategy for 2000 yang 
merupakan blueprint Amerika Serikat dalam upaya menanggulangi money laundering telah dikemukakan bahwa kejahatan tersebut relatif mudah untuk diucapkan, akan tetapi sulit dilakukan investigasi dan penuntutan. Khususnya seseorang yang melakukan transaksi keuangan dengan ketentuan bahwa dana atau kekayaan yang dilakukan transaksi itu adalah hasil kejahatan.

Financial Action Task Force Money Laundering (FATF) merumuskan bahwa money laundering adalah proses menyembunyikan atau menyamarkan asal-usul hasil kejahatan. Proses tersebut untuk kepentingan penghilangan jejak sehingga memungkinkan pelakunya menikmati keuntungan-keuntungan itu dengan tanpa mengungkapkan sumber perolehan (M. Arief Amrullah, 2004: 8-9).

Menurut Loeqman, pencucian uang terjemahan dari money laundering sering diartikan sebagai salah satu cara untuk menghalalkan uang haram dan yang dimaksud dengan uang haram bisa uang yang didapat dari suatu kejahatan, bisa pula berupa pengampunan pajak oleh pemerintah. Sehingga seorang tidak perlu lagi mempersoalkan pajak terhadap sejumlah kekayaan itu (Loebby Loeqman, 1996: 2).

Pembahasan anatomi
pencucian uang (money laundering), dapat dilihat Ketentuan dari United Nation Convention Againts Illicif Traffict in Narcotic Drugs and Psychotropyc Substances tertanggal 19 November 1991. Negara yang menandatangangi berjumlah 106, sendagkan yang sudah meratifikasinya berjumlah 46 negara. Konvensi tersebut mengatur perbuatan-pertbuatan yang termasuk money laundering dalam artikel (Offences and Sanction) pada butir (b) dan (c). Menurut Prof. Dr. M. Giovanoli dan Mr. J. Koers yang telah dikutip oleh Bambang Setijorodjo bahwa:

1) Money laundering merupakan suatu proses dan dengan cara seperti itu, maka aset yang diperoleh dari tindak pidana (kejahatan, penulis) dimanipulasikan sedemikian rupa sehingga aset tersebut selalu berasal dari sumber yang sah (legal)

2) Money laundering merupakan suatu cara untuk mengedarkan hasil kejahatan ke dalam suatu peredaran uang yang sah dan menutupi asal usul uang tersebut (M. Arief Amrullah, 2004: 10)

Pengertian money

laundering menurut UndangUndang Nomor 15 Tahun 2002 tercantum dalam Pasal 1 ayat (1) ialah, "Perbuatan menempatkan, mentransfer, membayar, membelanjakan, menghibahkan, menyumbangkan, menitipkan, membawa ke luar negeri, menukarkan, atau perbuatan lainnya atas harta kekayaan yang dietahui atau patut diduga merupakan hasil tindak pidana dengan maksud untuk menyembunyikan, atau menyamarkan asal usul harta kekayaan seolah-olah menjadi harta kekayaan yang sah".

b. Tahap-tahap dan Proses Pencucian Uang Proses terjadinya pencucian uang dapat dijelaskan bahwa terdapat berbagai macam operasi pencucian uang, namun pada dasarnya proses pencucian uang dapat dikelompokkan ke dalam tiga tahap kegiatan yaitu:

1) Placement. Tahap ini merupakan tahap pertama,yaitu pemilik uang tersebut mendepositkan uang haram tersebut ke 
dalam sistem keuangan

(financial sistem)

2) Layering. Yaitu memindahkan uang hasil kejahatan dari suatu bank ke bank yang lain dan dari negara satu ke negara yang lain sampai beberapa kali yang pelaksanaannya dilakukan dengan cara memecahkan jumlahnya, sehingga dengan pemecahannya dan pemindahan beberapa kali asal usul uang tersebut tidak dapat dilacak oleh otoritas moneter atau para penegak hukum.

3) Intergration. Upaya menggunakan harta kekayaan yang telah tampak sah atau uang halal (clean money), baik untuk dinikmati langsung, diinvestasikan ke dalam berbagai bentuk kekayaan material maupun keuangan, dipercayakan untuk membiayai kegiatan bisnisnya yang sah, ataupun untuk membiaya kembali tindak pidana.

Menurut Anwar Nasution, ada empat (4) faktor yang dilakukan dalam proses pencucian uang, yaitu:

1) Merahasiakan siapa pemilik yang sebenarnya maupun sumber uang hasil kejahatan itu.

2) Mengubah bentuknya sehingga mudah dibawa kemana-mana

3) Merahasiakan proses pencucian uang sehingga menjadikan pelacakannya oleh petugas hukum

4) Mudah diawasi oleh pemilik kekayaan yang sebenarnya (Adrian Sutedi, 2006: 82) Ada beberapa modus operandi yang sering digunakan dalam melakukan kejahatan pencucian uang antara lain; kerjasama penanaman modal, agunan kredit Bank Swis, transfer ke luar negeri, usaha tersamar di dalam negeri, penyamaran dokumen, pinjaman luar negeri, rekayasa pinjaman luar negeri.

c. Tinjauan tentang UndangUndang Tindak Pidana Pencucian Uang

Diundangkannya

Undang-Undang Nomor 25 Tahun 2003 Tentang Perubahan Atas Undang-Undang Nomor 15 Tahun 2002 Tentang Tindak Pidana Pencucian Uang merupakan suatu langkah besar dalam upaya membangun rezim pemberantasan tindak pidana pencucian uang (money laundering) di Indonesua. Dilihat dari sistematikan Undang-Undang Nomor 23 Tahun 2003 Tentang Tindak Pidana Pencucian Uang, maka ruang lingkup yang akan diberantas terdiri dari dua (2) kelompok tindak pidana ialah:

Pertama : Kelompok Tindak Pidana dalam Bab II yang berjudul "Tindak Pidana Pencucian Uang" yaitu delik-delik yang langsung berhubungan dengan perbuatan tindak pidana pencucian uang (diatur dalam Pasal 2,3,4,5,6,7).

Kedua : Kelompok Tindak Pidana dalam Bab III yang berjudul "Tindak Pidana Lain Yang Berkaitan Dengan Tindak Pidana Pencucian Uang", yaitu delik-delik yang berhubungan dengan proses pelaporan, penyidikan, penuntutan tindak pidana pencucian uang (diatur dalam Pasal 8, 9, 10, 11, $12,17 \mathrm{~A})$. 


\section{Metode Penelitian}

Penelitian termasuk jenis penelitian hukum non doktrinal atau penelitian hukum empiris. Jenis data yang dipergunakan dalam penelitian ini adalah berupa data primer yaitu data yang diperoleh secara langsung dari lapangan penelitian melalui wawancara terhadap subyek yang diteliti. Selain data primer, diperoleh pula melalui studi kepustakaan, bahan-bahan dokumenter, tulisan ilmiah dan hasil penelitian lain. Analisis data dalam penelitian ini adalah dengan menggunakan analisa kualitatif pola berpikir deduktif dan induktif secara kombinasi.

\section{Hasil Penelitian dan Pembahasan}

1. Peran Bank Indonesia Dalam Menanggunlangi Tindak Pidana Money Laundering

Bank Indonesia adalah Bank Sentral Republik Indonesia menurut ketentuan Pasal 4 ayat (1) UndangUndang Republik Indonesia Nomor 3 tahun 2004 tentang Perubahan Atas Undang-Undang Republik Indonesia Nomor 23 Tahun 1999 tentang Bank Indonesia, Bank Indonsia mempunyai kewajiban melakukan pembinaan dan pengawasan bank di seluruh wilayah Republik Indonesia. Hal tersebut sesuai ketentuan Pasal 29 UndangUndang Nomor 10 Tahun 1998 tentang Perubahan Atas UndangUndang Nomor 7 Tahun 1992 Tentang Perbankan. Bank Indonesia melakukan pemeriksaan terhadap bank, baik secara berkala maupun setiap waktu apabila diperlukan.

Selain itu Bank Indonesia dalam melaksanakan tugas pembinaan dan pengawasan bank dapat meminta bantuan akuntan publik untuk dan atas nama Bank Indonesia melaksanakan pemeriksaan terhadap bank. Hasil laporan pemeriksaan bank dirahasiakan untuk mengantisipasi adanya hal-hal yang tidak diinginkan.

Bank Indonesia Pusat di Jakarta dalam operasional pelaksanaan tugasnya di bantu oleh Bank Indonesia yang berkedudukan di kota propinsi maupun kotamadya. Dalam rangka ikut serta menanggulangi tindak pidana money laundering, maka Bank Indonesia telah mengeluarkan beberapa Peraturan Bank Indonesia dan Syarat Edaran Bank Indonesia, dengan tujuan agar pelaksanaan anti pencucian uang oleh bank umum dapat berjalan sesuai yang diharapkan.

Menurut ketentuan Pasal 2 dan 3 Peraturan Bank Indonesia Nomor: 11/28/PBI/2009 tentang Penerapan Program Anti Pencucian Uang dan Pencegahan Pendanaan Terorisme bagi Bank Umum bahwa;

1. Bank wajib menerapkan program APU dan PPT

2. Dalam penerapan program APU dan PPT, Bank wajib berpedoman pada ketentuan yang dalam Peraturan Bank Indonesia

3. Program APU dan PPT merupakan bagian dari penerapan menejemen resiko bank secara keseluruhan

4. Penerapan program APU dan PPT paling kurang mencakup:

a. pengawasan aktif Direksi dan Dewan Komisaris

b. kebiajkan dan prosedur

c. pengendalian intern

d. sistem informasi manajemen

e. sumber daya manusia dan pelatihan

Dalam melaksanakan

pengawasan aktif direksi dan dewan komisaris, Bank Indonesia memerlukan suatu kepastian tentang apakah bank telah memiliki kebijakan dan prosedur program APU dan PPT, memastikan penerapan APU dan PPT dilaksanakan sesuai dengan kebijakan dan prosedur tertulis yang telah diterapkan, serta memastikan bahwa satuan kerja yang melaksanakan kebijakan dan prosedur program APU dan PPT terpisah dari satuan kerja yang mengawasi penerapannya.

Menurut penjelasan dari Kepala Bagian Kelompok Kajian Statistik dan Survei Bank Indonesia di Solo bahwa pemisahan satuan kerja dalam melaksanakan kebijakan dan prosedur program APU dan PPT dan satuan kerja pengawasan adalah agar tidak terjadi adanya tumpang 
tindih dalam pelaksanaan kerja serta adanya pemisahan pertanggungjawaban yang jelas dalam pelaksanaan kerja antara satuan kerja.

$$
\text { Selanjutnya dikatakan }
$$

bahwa setiap bank wajib membentuk unit kerja khusus atau kalau tidak, dapat menunjuk salah satu pejabat bank yang bertanggung jawab atas penerapan program APU dan PPT. Para anggota unit kerja khusus tersebut haruslah orang-orang atau pejabat bank yang memiliki kemampuan yang memadai dan memiliki kewenangan untuk mengakses seluruh data Nasabah dan informasi lain yang terkait. Dalam pelaksanaan tugasnya unit kerja khusus tersebut akan bertanggung jawab kepada Direktur Kepatuhan. Direktur Kepatuhan inilah yang membantu pimpinan bank dalam melakukan pemantauan terhadap pelaksanaan program APU dan PPT berdasarkan Peraturan Bank Indonesia dan Surat Edaran yang telah dikeluarkan Bank Indonesia.

Berdasarkan ketentuan Pasal

7 Peraturan Bank Indonesia Nomor: 11/28/PBI/2009 tentang Penerapan ProgranmAnti Pencucian Uang dan Pencegahan Pendanaan Terorisme bagi Bank Umum maka pejabat unit kerja khusus atau pejabat yang bertanggung jawab terhadap program APU dan PPT wajib:

a. memantau adanya sistem yang mendukung program APU dan PPT

b. memantau keesahan dari profil nasabah

c. melakukan koordinasi dan pemantauan terhadap pelaksanaan kebijakan program APU dan PPT dengan satuan unit kerja serta unit unit kerja yang berhubungan dengan nasabah seperti unit kerja keuangan bank dan unit kerja penelitian dan pengenalan nasabah.

d. memastikan bahwa kebijakan dan prosedur telah seusai perkembangan program APU dan PPT yang terkini, resiko produk bank, kegiatan dan kompleksitas usaha bank, dan volume transaksi dari bank.

e. menerima laporan transaksi keuangan yang berpotensi mencurigakan (red plag) dari unit kerja terkait yang berhubungan dengan nasabah dan melakukan analisis atas laporan tersebut.

f. menyusun laporan transaksi keuangan mencurigakan dan kaporan lainnya yang berhubungan dengan tindak pidana pencucian uang sebagaimana telah diatur dalam Undang-Undang Tindak Pidana Pencucian Uang (UndangUndang Nomor 25 Tahun 2003 Tentang Perubahan Atas Undang-Undang Nomor 15 Thun 2002 Tentang Tindak Pidana Pencucian Uang). Kemudian hasil laporan tersebut dapat disampaikan kepada Pusat Pelaporan dan Analisis Transaksi Keuangan (PPATK) atas persetujuan Direktur Kaptuhan setelah mencapat izin dari Bank Indonesia.

g. memantau apakah telah terjadi komunikasi yang baik dari setiap unit kerja terkait terhadap penerapan program APU dan PPT dengan menjaga kerahasiaan informasi.

h. Unit kerja terkait melakukan fungsi dan tugas dalam rangka persiapan laporan apabila terjadi dugaan Transaksi Keuangan Mencurigakan sebelum menyampaikan kepada Unit Kerja Khusus atau pejabat yang bertanggung jawab terhadap penerapan program APU dan PPT.

i. memantau, menganalisa, dan merekomendasikan kebutuhan pelatihan program APU dan PPT bagi pegawai bank.

Semua pelaksanaan tugas unit kerja khusus yang ada di bank umum wajib dipertanggungjawabkan kepada Direktur Kepatuhan Bank. Kemudian Direktur Kepatuhan Bank akan menyeleksi dan menganalisis hasil pertanggungjwaban unit kerja khusus bank dan selanjutnya Direktur 
Kepatuhan akan melaporkan hasil seleksi dan analisis dari tugas unit kerja khusus bank dalam melakukan pemantauan dan pemeriksaan penerapan program APU dan PPT dari Bank kepada Pengawas Bank Muda Senior pada Kelompok Pengawasan Bank I dan selanjutnya berkas laporan tersebut dilaksanakan audit dan analisis sebelum diserahkan kepada Deputi Pemimpin Bank Indonesia Bidang Pengawasan Bank Kantor Bank Indonesia Solo untuk dilakukan pengesahan laporan.

$$
\text { Dalam melaksanakan }
$$

kewajiban melakukan pembinaan dan pengawasan terhadap penerapan Program APU dan PPT bagi bank umum, maka Deputi Pemimpin Bank Indonesia Bidang Pengawasan dibantu oleh Pengawas Bank Muda Senior, Pengawas Bank Muda serta Pengawas Bank Pertama pada Kelompok Pengawasan Bank I dan II dapat melakukan pemeriksaan secara langsung satu tahun sekali secara berkala maupun setiap waktu apabila diperlukan, untuk memastikan apakah bank telah menerapkan program anti pencucian uang dan pencegahan pendanaan terorisme menurut ketentuan Pasal 8 Peraturan Bank Indonesia Nomor: 11/28/PBI/2009 yang menentukan antara lain bahwa bank wajib memiliki kebijakan dan prosedur tertulis yang paling kurang mencakup:
a. permintaan informasi dan dokumen ;
b. Beneficial Owner
c. verifikasi dokumen ;
d. CDD yang lebih sederhana ;
e. penutupan hubungan dan penolakan transaksi ;

f. ketentuan mengenai area resiko tinggi dan PEP ;

g. pelaksanaan CDD oleh pihak ketiga ;

h. pengkinian dan pemantauan

i. Cross Border Correspondent Banking

j. transfer dana dan

k. penatausahaan dokumen

$\begin{array}{rrr}\text { Bank } & \text { Indonesia } & \text { selain } \\ \text { mengeluarkan } & \text { Peraturan } & \text { Bank }\end{array}$ Indonesia Nomor: 11/28/PBI/2009, juga mengeluarkan Surat Edaran Tentang Nasabah kepada semua Bank Umum di Indonesia. Pedoman Standar Penerapan Prinsip Mengenai Nasabah (Know Your Customer Principles) yang merupakan salah satu upaya juga untuk mencegah agar sistem perbankan tidak digunakan sebagai sarana kejahatan pencucian uang (money laundering), baik yang dilakukan secara langsung maupun tidak langsung oleh pelaku kejahatan. Pedoman Standar Penerapan

Prinsip Mengenal Nasabah menguraikan tentang kebijakan umum, prosedur penerimaan dan identifikasi nasabah, pemantauan dan pelaporannya serta pelatihan karyawan.

Setiap Bank Umum wajib membentuk Unit Kerja Khusus yang menangani tentang Prinsip Mengenal Nasabah, tetapi apabila berdasarkan pertimbangan beban tugas operasional kompleksitas usahanya ternyata bank memandang belum membutuhkan Unit Kerja Peneraoan Prinsip Mengenal Nasabah maka bank dapat menunjuk seorang pejabat bank yang melaksanakan tugas Unit Kerja Penerapan Prinsip Mengenal Nasabah serta bertanggungjawba kepada Direktur Kepatuhan Bank..

Berdasarkan Surat Edaran Perihal Penerapan Standar Penerapan Mengenal Nasabah, maka bank wajib mempunyai kebijakan tentang penerimaan dan identifikasi calon nasabah yang sekurang-kurangnya mencakup hal sebagai berikut.

a. Permintaan informasi mengenai calon nasabah antara lain:

1. identitas calon nasabah

2. maksud dan tujuan hubungan usaha yang akan dilakukan oleh calon nasabah dengan Bank

3. informasi lain yang memungkinkan Bank untuk dapat mengetahui profil calon nasabah

4. identitas pihak lain, dalam hal calon nasabah bertindak untuk dan atas nama pihak lain. 
b. Permintaan bukti-bukti identitas dan dokumen pendukung informasi dari calon nasabah

c. Penelitian atas kebenaran buktibukti identitas dan dokumen pendukung informasi dari calon nasabah

d. Pertemuan dengan calon nasabah dilakukan sekurang-kurangnya pada saat pembukaan rekening termasuk pembukaan rekening secara elektronis.

e. Apabila dipandang perlu dapat dilakukan wawancara dengan calon nasabah untuk memperoleh keyakinan atas kebenaran informasi, bukti-bukti identitas dan dokumen pendukung calon nasabah.

f. Menolak calon nasabah yang tidak memenuhi kelengkapan informasi, bukti-bukti identitas dan dokumen pendukung lainnya dan/atau diragukan kebenarannya.

$$
\text { Selain mengatur tentang }
$$

Kebijakan Penerimaan dan Identifikasi Nasabah, Surat Edaran Bank Indonesia juga mengatur tentang Kebijakan Pemantauan dan Pelaporan dari rekening dan transaksi nasabah.

Menurut Kepala Kelompok Kajian Statistik dan Survei Kantor Bank Indonesia Solo, pemeliharaan profil nasabah sangat penting sekali karena merupakan tindakan preventif dalam rangka menanggulangi tindak pidana pencucian uang (money loundering). Agar pelaksanaanya dapat berjalan sesuai dengan apa yang diharapkan, maka setiap bank wajib membuat pedoman Prinsip Mengenal Nasabah, bank juga wajib melakukan pelatihan terhadap karyawannya dalam mengenal nasabah, selain itu diperlukan strategi yang handal dalam mendeteksi nasabah.

Tujuan pelatihan tersebut adalah agar karyawan selaku memperoleh pengetahuan dan informasi yang terkini. Latihan ini harus dilakukan secara berkala dan berkesinambungan

$$
\text { Menurut informasi dari }
$$

Bank Indonesia Solo, bahwa latihan tersebut harus dilatih oleh pelatih yang sudah pernah mengikuti Diklat tentang Penerapan Prinsip Mengenal Nasabah yang diselenggarakan di Bank Indonesia Pusat Jakarta dan telah memperoleh sertifikat sebagai pelatih. Jangka waktu latihan 2 (dua) minggu atau tergantung situasi dan kondisinya. Selanjutnya karyawankaryawan bank yang telah mendapat pelatihan tentang penerapan prinsip mengenal nasabah akan melaksanakan tugas pada unit kerja khusus yang bertanggungjawab atas penerapan program APU dan PPT sesuai ketentuan Pasal 7 Peraturan Bank Indonesia Nomor 11/28/PBI/2009. Hasil pelaksanaan tugas unit kerja khusus tersebut di atas kemudian dipertanggungjawabkan kepada Bank Indonesia untuk mendapat pengesahan.

2. Kendala Yang Dihadapi Bank Indonesia Dalam Menanggulangi Tindakan Pidana Money laundering Kantor Bank Indonesia Solo telah berusaha semaksimal mungkin untuk membantu Bank Indonesia Pusat di Jakarta untuk ikut berperan dalam menanggulangi tindak pencucian uang (money laundering) sesuai peraturan yang ada, namun demikian ternyata dalam pelaksanaanya mengalami beberapa kendala yang menyebabkan dalam melaksanakan tugasnya dirasakan kurang begitu maksimal. Kendalakendala tersebut antara lain:

a. Undang-Undang No. 25 Tahun $2003 \quad$ Tentang Perubahan Atas UndangUndang No.15 Tahun 2002 Tentang Tindak Pidana Pencucin Uang hanya memperhatikan yang simpanan berjumlah Rp. 100.000.000 (seratus juta rupiah) keatasnya saja dan tanpa memperhatikan simpanan dibawah Rp. 100.000.000 (seratus juta rupiah) yang kemungkikan uang tersebut juga hasil dari kejahatan. 
b. Adanya pemecahan dana nasabah dengan identitas yang berbeda-beda di Bank, cabang bank atau Anak Cabang Bank sehingga dapat terhindar dari dugaan adanya transaksi keuangan yang tidak wajar yang terkait dengan tindak pidana money laundering. Hal tersebut sering banyak dilakukan oleh Beneficial Owner.

c. Karena keahlian nasabah dalam penguasaan teknologi informasi, sehingga memudahkan nasabah tersebut untuk meminjam dan mengambil dananya dari hasil kejahatan. Tidak terdekteksi keadaan tersebut, karena kurnagnya SDM yang menguasai teknologi informasi yang lebih cnggih dari Bank maupun Bank Indonesia sendiri.

d. Sering diketemukan adanya kekurangan-kekurangan dalam menentukan kebijakan dan prosedur tertulis dalam menerapkan program APU dan PPT pada saat Bank Indonesia melakukan pemeriksaan secara langsung.

e. Pada saat Bank Indonesia Solo melakukan pemeriksaan terhadap Bank, sebenarnya dirasakan ada ketidakjujuran terutama dalam hal pencatatan palsu dalam pembukuan, pembuatan proses laporan, dalam dokumen atau laporan kegiatan usaha, laporan transaksi atau rekening suatu bank, namun Bank Indonesia Solo sulit membuktikannya karena adanya kekurangan sumber daya manusia yang profesional untuk mengambil tenaga audit dari luar pun terkadang kejujurannya diragukan.

f. Bank Indonesia Solo dan Bank yang ada di wilayah Solo sebenarnya kesulitan untuk melacak adanya indikasi tentang dugaan telah terjadi tindak pidana pencucian uang, karena tindak pidana pencucian uang merupakan white collor crime yang menggunakan modus sangat halus tanpa kekerasan, tetapi selalu diikuti dengan kecurangan, penyesatan, penyembunyian

kenyataan, manipulasi, pelanggaran kepercayaan, akal-akalan atau pengelakan terhadap peraturan, sehingga pemantauannya serta pengawasannya cukup sulit.

\section{E. Simpulan}

Peran Bank Indonesia dalam rangka ikut serta menanggulangi tindak pidana money laundering telah mengeluarkan Peraturan serta Surat Edaran Bank Indonesia. Kantor Bank Indonesia Solo setiap triwulan secara berkala atau setiap saat kalau diperlukan menerima laporan atau melakukan pemeriksaan secara langungsun kepada Bank Umum untuk memastikan apakah Bank telah menerapkan Peraturan Program Anti Pencucian Uang Dan Pencegahan Pendanaan Terorisme serta melaksanakan Pedoman Standar Penerapan Mengenal Nasabah. Meskipun telah ada Peraturan dan Surat Edaran Bank Indonesia namun dalam pelaksanaan tugas untuk ikut serta menanggulangi tindak pidana money laundering sering mengalami kendala, hal tersebut disebabkan karena kurangnya tenaga profesional.

\section{F. Saran}

1. Untuk mengantisipasi kurangnya tenaga profesional dalam melaksanakan tugas 
untuk ikut serta menanggulangi tindak pidana pencucian uang maka Bank Indonesia Solo perlu melaksanakan pelatihan-pelatihan secara periodik kepada para karyawan dan karyawan baru bank dalam hal penerapan mengenal nasabah.

2. Perlu lebih ditingkatkan pelaksanaan tugas pengawasan, pemantauan,

pemeriksaan dan pembinaan oleh Bank Indonesia Solo terhadap penerapan Program Anti Pencucian Uang oleh Bank, Kantoir Cabang Bank dan Anak Cabang Bank agar terhindar dari penyalahgunaan Bank untuk sarana melakukan tindak pidana money laundering.

3. Perlu adanya kerjasama antara bank dalam menyusun laporan tentang

penerapan program anti pencucian uang dengan koordinator Bank Indonesia.

4. Perlu dibentuk suatu Unit Kerja Khusus untuk melakukan pemantauan

terhadap hasil yang dapat dicapai setelah para pegawai dan pegawai baru bank dalam mengikuti program latihan untuk melaksanakan Pedoman Standart Penerapan Prinsip Mengenal Nasabah. 
Daftar Pustaka

Adrian Sutedi. 2006. Perlindungan Konsumen, Pencucian Uang dan Merger SahamBank. Jakarta: BP. Cipta Jaya.

Burhan Ashsofa. 1996. Metode Penelitian Hukum. Jakarta: Bineka Cipta

Hermansyah. 2005. Hukum Perbankan Indonesia Dalam Hukum Positif.. Jakarta: Kencana

Koesparmono Irsan. “Dimensi Lain Cuci Tangan. Bonus” Infobank. Edisi September No, 201/1996.

.Loebby Loeqman. 1996. “Dilema Cuci Uang, Bonus” Infobank, Edisi September No. $201 / 1996$.

M. Arief Amrullah. 2004. Money Laundering ( Tindak Pidana Pencucian Uang ). Jember: Bayumedia Publishing

Munir Faudy. 2001. Hukum Perbankan Modern. Jilid I. Bandung: PT. Citra Aditya Bakti

.Ronny Hanitijo Soemitro. 1988. Metodologi Penelitian Hukum dan Jurimetri. Semarang: Ghalia Indonesia

Soerjono Soekanto. 1994. Pengantar Penelitian Hukum.. Jakarta: UI - Press

Siahaan. 2002. Pencucian Uang dan Kejahatan Perbankan. Jakarta: Pustaka Sinar Harapan

Undang-Undang Nomor 7 Tahun 1992 Tentang Perbankan.

Undang-Undang Nomor 10 Tahun 1998 Tentang Perubahan Atas Undang-Undang Nomor 7 Tahun 1992 Tentang Perbankan.

Undang-Undang Nomor 3 Tahun 2004 Tentang Perubahan Atas Undang-Undang Nomor 23 Tahun 1999 Tentang Bank Indonesia.

Undang-Undang Nomor 15 Tahun 2002 Tentang Tindak Pidana Pencucian Uang

Undang-Undang Nomor 8 Tahun 2010 Tentang Tindak Pidana Pencucian Uang 